\title{
Cats singing in the dark? Spawning aggregations of sound-producing fish in Amazonian floodplain forests
}

\author{
Peter van der Sleen • Arnold Lugo-Carvajal • \\ Jansen Zuanon • Milena Holmgren
}

Received: 15 July 2020 / Accepted: 9 August 2020 / Published online: 15 August 2020

(C) The Author(s) 2020

\begin{abstract}
The Amazon basin has a freshwater fish diversity comparable to a tropical sea. Although many Amazonian fish species are popular ornamental fish across the world, the ecology of most species in their natural habitat remains poorly known (van der Sleen and Albert 2017). We report on shoaling behavior in Platydoras hancockii in a floodplain forest of the middle Rio Negro, Brazil. As the shoal consisted of only adult males, whereas gravid females were caught individually in nearby areas, we hypothesize that this aggregation may relate to spawning. Moreover, considering that Platydoras hancockii is capable of producing sounds, it is possible that these aggregations entail the formation of a chorus-like call with the function of attracting females from a larger area.
\end{abstract}

Electronic supplementary material The online version of this article (https://doi.org/10.1007/s10641-020-01019-x) contains supplementary material, which is available to authorized users.

P. van der Sleen $(\triangle) \cdot$ A. Lugo-Carvajal $\cdot$ M. Holmgren Wildlife Ecology and Conservation Group, Wageningen University and Research Centre, Wageningen, The Netherlands e-mail: peter.vandersleen@wur.nl

P. van der Sleen

Forest Ecology and Forest Management Group, Wageningen University and Research Centre, Wageningen, The Netherlands

\section{A. Lugo-Carvajal}

Programa de Pós-Graduação em Biologia de Água Doce e Pesca Interior, Instituto Nacional de Pesquisas da Amazônia (INPA), Manaus, Brazil

\section{J. Zuanon}

Coordenação de Biodiversidade, Instituto Nacional de Pesquisas da Amazônia (INPA), Manaus, Brazil
Keywords Spawning aggregation $\cdot$ Gender segregation $\cdot$ Chorus $\cdot$ Freshwater fish . Platydoras hancockii $\cdot$ Amazon basin

A predictable flood pulse in the Amazon basin inundates floodplain forests at vast spatial scales for several months each year, thereby creating crucial feeding and nursery grounds for Amazonian fish (e.g., Goulding 1980). How individuals of the same fish species find each other during this reproduction period and how mate selection takes place in these immense, shaded, and often murky waters remains largely unknown.

During the high-water season, on May 16, 2019, we collected a shoal of 28 individuals of the raphael catfish Platydoras hancockii (Siluriformes: Doradidae) in a blackwater floodplain forest (Fig. 1a, b), about $5 \mathrm{~km}$ from the town of Barcelos in the Mariuá Archipelago, middle Rio Negro, Brazil $\left(0.56^{\circ} \mathrm{S}, 62.55^{\circ} \mathrm{W}\right)$. The sampling was part of a larger research project on the effects of floodplain forest loss by fire on fish communities (Lugo-Carvajal et al. in prep.). The fish were caught within an unburned floodplain forest and were retrieved from the net at $11 \mathrm{am}$, but probably got entangled at night or crepuscular hours. All individuals were collected close together and within a few meters of a gillnet of $60 \mathrm{~mm}$ mesh size in an area of about $1.2 \mathrm{~m}$ depth.

Strikingly, all individuals in this aggregation were adult males, with a size range of 135-180 mm SL and a weight range of $31-105 \mathrm{~g}$. Sex determination for this species is difficult based on external morphological traits only, and was hence established anatomically after euthanizing the 


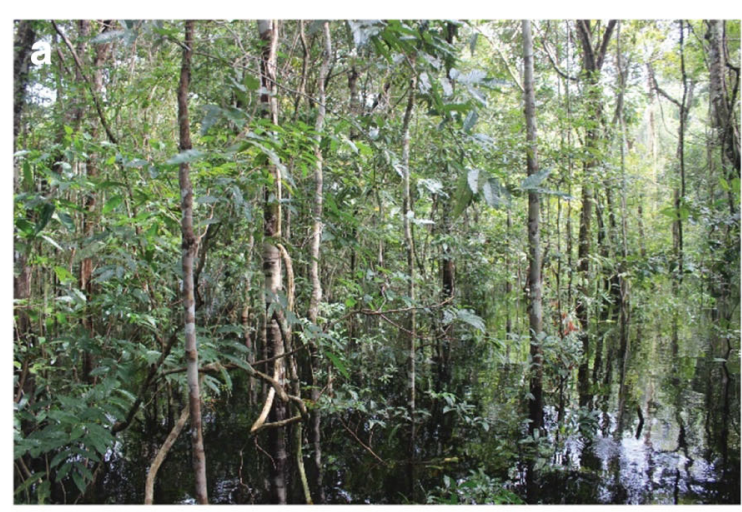

C

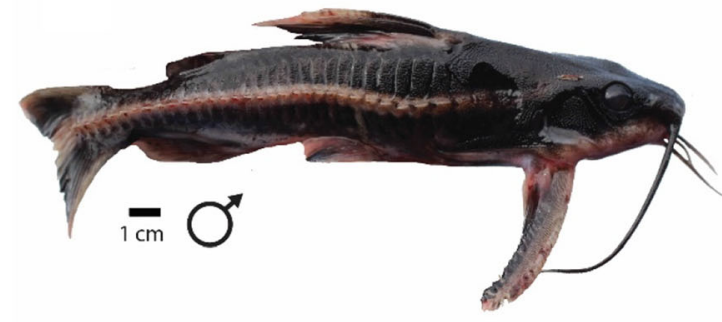

Fig. 1 Floodplain forest in the middle Rio Negro, Brazil (a). Collection of male Platydoras hancockii; individuals after retrieving them from the gillnet (b). The genus Platydoras consists of four species, with $P$. hancockii restricted to the upper Orinoco, Negro, Essequibo and Demerara drainages (Piorski et al. 2008). Platydoras species feed primarily on invertebrates, snails, bivalves

fish with an eugenol solution. In the same area, and at the same day and time, but apart from this group (less than $20 \mathrm{~m}$ ), we collected a large gravid female of $180 \mathrm{~mm} \mathrm{SL}$ (Fig. 1d) suggesting this assembly may relate to spawning. Individual females were also collected in nearby sites during the same sampling period. Shoaling behavior in catfish is not common, but has been reported for several species, including most Corydoras species (e.g., Paxton 1997; Breeland and Strauss 2005). For "Amblydoras hancockii" from French Guyana, Le Bail et al. (2000) reported it occurred in shoals of several hundred. Surprisingly, that information has subsequently been put under Platydoras hancockii in two major online databases (Eschmeyer's Catalog of Fishes and FishBase), but the photograph accompanying Le Bail's description appears to be a species of the genus Anadoras.

Male aggregations in Platydoras hancockii may be facilitated by its sound producing behavior. During the moment of capture, the fish were producing squeaking sounds (see Online Resource 1 for a short video of the moment of capture). In doradid catfishes, sounds are produced by the friction of the pectoral-fin spine against the
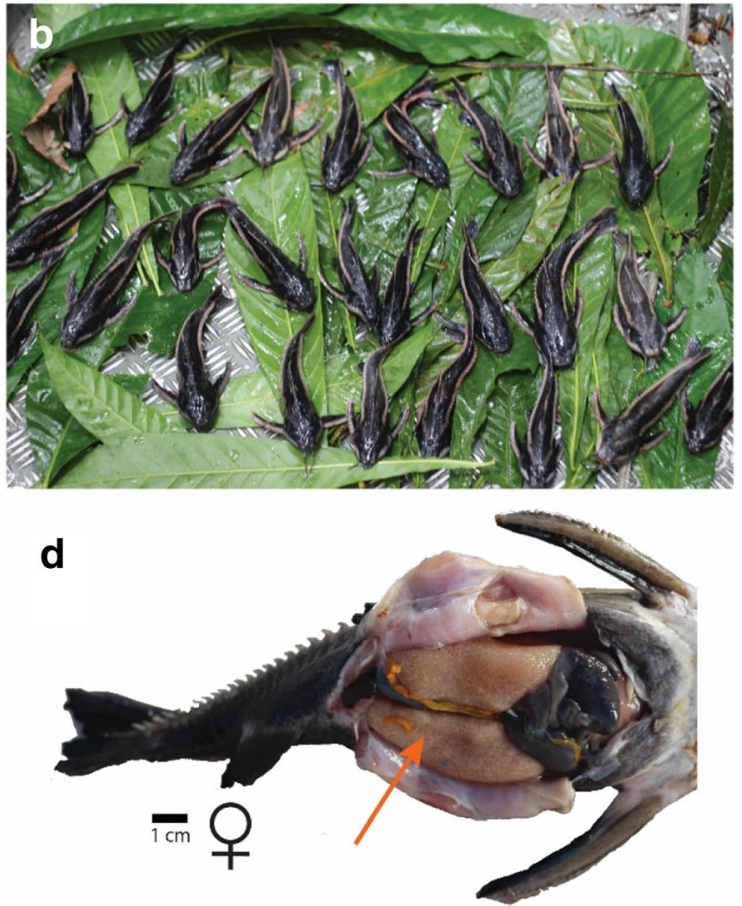

and detritus (Le Bail et al. 2000; Sousa et al. 2017). Some species may also exhibit cleaning behavior as juveniles, picking of parasites from larger predatory fish, and the strongly contrasting black and white coloration may function as a signal for being recognized as a cleaner (Carvalho et al. 2003). Close-up of a male (c) and a large gravid female, with orange arrow indicating eggs (d)

pectoral girdle (Ladich 2001), and by the contraction of muscles that move the parapophyses of the fourth vertebra (Müllerian ramus) and gas bladder, in a special arrangement named the elastic spring apparatus (Boyle et al. 2015). Although the doradid sonic mechanism appears relatively simple, the drumming sounds produced can be quite complex and exhibit variation in pulse rate, temporal patterning, waveform shape, and amplitude modulation (Kastberger 1978; Papes and Ladich 2011; Kaatz and Stewart 2012; Knight and Ladich 2014). Sounds are likely species-specific, and for $P$. hancockii three distinguishable sound types have been recorded (Boyle et al. 2015).

The advantage of using audial signals is that they propagate fast and in all directions, unlike olfactory cues, which travel downstream from the sender under lotic conditions, and to longer distances than visual signals, which quickly weaken with increasing distance in dark waters such as those of the Rio Negro. We hypothesize that the observed group of $P$. hancockii males may be related to the collective production of sounds. When three or more nearby animals have calls that overlap or are produced in rapid succession, this pattern of sound 
production is referred to as a chorus (Greenfield and Shaw 1983), a fact that have been reported for several marine fishes (e.g. batrachoidids and sciaenids, Amorim et al. 2015; and ariid catfishes, Tavolga 1960). In the Amazon freshwaters there are also records of choruses by the sciaenid Plagioscion squamosissimus (Borie et al. 2014) and by several characiform species of the families Curimatidae and Prochilodontidae (Smith et al. 2017). However, as far as we know, there were no published evidences of choruses by freshwater catfishes. The louder sounds produced by the group could propagate information on their presence over a larger area, increasing the effectiveness of attracting females and possibly reproductive success. Such a strategy may be particularly advantageous in the Amazon during the flooding season, given the immense size of the wetscape during that time of the year. Although anecdotal, our observation provides a glimpse of the complex social behavior fish can exhibit, and highlights the importance of floodplain forests as spawning areas for Amazonian fish.

Acknowledgments The authors would like to thank the National Geographic Society (Grant NGS-165R-18) for financial support of the fieldwork; the Fundação de Amparo à Pesquisa do Estado do Amazonas for a student grant for AL-C; PvdS was partially funded by a MSCA-IF grant of the European Commission (no. 746181); JZ received a productivity grant from the Brazilian CNPq (\#313183/2014-7). The authors thank Daniel Brito Porto for his help in the field. This research was conducted with approved permits by the animal care committee of the National Institute for Research in the Amazon (INPA, Portuguese acronym), Manaus, Amazonas state, Brazil (Protocol nr. 033/2012).

Open Access This article is licensed under a Creative Commons Attribution 4.0 International License, which permits use, sharing, adaptation, distribution and reproduction in any medium or format, as long as you give appropriate credit to the original author(s) and the source, provide a link to the Creative Commons licence, and indicate if changes were made. The images or other third party material in this article are included in the article's Creative Commons licence, unless indicated otherwise in a credit line to the material. If material is not included in the article's Creative Commons licence and your intended use is not permitted by statutory regulation or exceeds the permitted use, you will need to obtain permission directly from the copyright holder. To view a copy of this licence, visit http://creativecommons.org/licenses/by/4.0/.

\section{References}

Amorim MCP, Vasconcelos RO, Fonseca PJ (2015) Fish sounds and mate choice. In: Ladich F (ed) Sound communication in fishes. Springer, Wien, pp 1-33
Borie A, Mok H-K, Chao NL, Fine ML (2014) Spatiotemporal variability and sound characterization in silver croaker Plagioscion squamosissimus (sciaenidae) in the central amazon. PLoS One 9(8):e99326

Boyle KS, Riepe S, Bolen G, Parmentier E (2015) Variation in swim bladder drumming sounds from three doradid catfish species with similar sonic morphologies. J Exp Biol 218(18):2881-2891

Breeland TB, Strauss RE (2005) School and shoal distributions in a freshwater catfish species, Corydoras paleatus (Callichthyidae). Integr Comp Biol 45(6):969-969

Carvalho LN, Arruda R, Zuanon J (2003) Record of cleaning behavior by Platydoras costatus (Siluriformes: Doradidae) in the Amazon Basin, Brazil. Neotropical Ichthyol 1(2):137-139

Goulding M (1980) The fishes and the forest: explorations in Amazonian natural history. University of California Press, Berkeley

Greenfield MD, Shaw KC (1983) Adaptive significance of chorusing with special reference to the Orthoptera. In: Gwynne DT, Morris GK (eds) Orthopteran mating systems: sexual competition in a diverse group of insects. Westview Press, Boulder, pp 1-27

Kaatz IM, Stewart DJ (2012) Bioacoustic variation of swimbladder disturbance sounds in Neotropical doradoid catfishes (Siluriformes: Doradidae, Auchenipteridae): potential morphological correlates. Curr Zool 58(1):171-188

Kastberger G (1978) Sound production in Doradidea and Auchenopteridea siluriformes pisces. Acta Amazon 8(3):455-468

Knight L, Ladich F (2014) Distress sounds of thorny catfishes emitted underwater and in air: characteristics and potential significance. J Exp Biol 217(22):4068-4078

Ladich F (2001) Sound-generating and-detecting motor system in catfish: design of swimbladder muscles in doradids and pimelodids. Anat Rec 263:297-306

Le Bail PY, Keith P, Planquette P (2000) Atlas des Poissons d'eau douce de Guyane. Tome 2, fascicule II: Siluriformes. Muséum National d'Histoire Naturelle, Paris, France

Papes S, Ladich F (2011) Effects of temperature on sound production and auditory abilities in the striped Raphael catfish Platydoras armatulus (family Doradidae). PLoS One 6(10):e26479

Paxton CGM (1997) Shoaling and activity levels in Corydoras. J Fish Biol 51(3):496-502

Piorski NM, Garavello JC, Arce M, Sabaj-Pérez MH (2008) Platydoras brachylecis, a new species of thorny catfish (Siluriformes: Doradidae) from Northeast Brazil. Neotropical Ichthyol 6(3):481-494

Smith ME, Weller KK, Kynard B, Sato Y, Godinho AL (2017) Mating calls of three prochilodontid fish species from Brazil. Environ Biol Fish 101:327-339

Sousa LM, Chaves MS, Akama A, Zuanon J, Sabaj MH (2017) Platydoras birindellii, new species of striped raphael catfish (Siluriformes: Doradidae) from the Xingu Basin, Brazil. Proc Acad Natl Sci Phila 166(1):1-13

Tavolga WN (1960) Sound production and underwater communication in fishes. In: Lanyon WE, Tavolga WN (eds) Animal sounds and communication. Intelligencer Printing Co., Washington DC, pp 93-136

van der Sleen P, Albert JS (2017) Field guide to the fishes of the Amazon, Orinoco and Guianas. Princeton University Press, Princeton, USA 